\title{
Estimating the efficiency of a small beam trawl for sampling tiger prawns Penaeus esculentus and $P$. semisulcatus in seagrass by removal experiments
}

\author{
N. R. Loneragan ${ }^{1}$, Y.-G. Wang ${ }^{2}$, R. A. Kenyon ${ }^{1}$, D. J. Staples ${ }^{3}$, D. J. Vance ${ }^{1}$, \\ D. S. Heales ${ }^{1}$ \\ ${ }^{1}$ CSIRO Division of Fisheries and ${ }^{2}$ CSIRO Biometrics Unit, Cleveland Marine Laboratories, PO Box 120, Cleveland, \\ Queensland 4163, Australia \\ ${ }^{3}$ Bureau of Resource Sciences, Department of Primary Industry and Energy, PO Box E11, Queen Victoria Terrace, \\ Canberra, ACT 2600, Australia
}

\begin{abstract}
The efficiency with which a small beam trawl $(1 \times 0.5 \mathrm{~m}$ mouth $)$ sampled postlarvae and juveniles of tiger prawns Penaeus esculentus and $P$. semisulcatus at night was estimated in 3 tropical seagrass communities (dominated by Thalassia hemprichii, Syringodium isoetifolium and Enhalus acoroides, respectively) in the shallow waters of the Gulf of Carpentaria in northern Australia. An area of seagrass $(40 \times 3 \mathrm{~m})$ was enclosed by a net and the beam trawl was repeatedly hand-hauled over the substrate. Net efficiency $(q)$ was calculated using 4 methods: the unweighted Leslie, weighted Leslie, DeLury and Maximum-likelihood (ML) methods. The Maximum-likelihood is the preferred method for estimating efficiency because it makes the fewest assumptions and is not affected by zero catches. The major difference in net efficiencies was between postlarvae (mean ML $q \pm 95 \%$ confidence limits $=$ $0.66 \pm 0.16$ ) and juveniles of both species (mean $q$ for juveniles in water $\leq 1.0 \mathrm{~m}$ deep $=0.47 \pm 0.05$ ), i.e. the beam trawl was more efficient at capturing postlarvae than juveniles. There was little difference in net efficiency for $P$. esculentus between seagrass types ( $T$. hemprichii versus $S$. isoetifolium), even though the biomass and morphologies of seagrass in these communities differed greatly (biomasses were 54 and $204 \mathrm{~g} \mathrm{~m}^{-2}$, respectively). The efficiency of the net appeared to be the same for juveniles of the 2 species in shallow water, but was lower for juvenile $P$. semisulcatus at high tide when the water was deeper $(1.6$ to $1.9 \mathrm{~m})(0.35 \pm 0.08)$. The lower efficiency near the time of high tide is possibly because the prawns are more active at high than low tide, and can also escape above the net. Factors affecting net efficiency and alternative methods of estimating net efficiency are discussed
\end{abstract}

KEY WORDS: Net efficiency $\cdot$ Beam trawls $\cdot$ Tiger prawns $\cdot$ Seagrass

\section{INTRODUCTION}

The distribution and relative abundance of juvenile crustaceans and fish have been studied by sampling with jet nets (Penn \& Stalker 1975, Turnbull \& Watson 1992), drop traps (Zimmerman et al. 1984) and beam trawls (e.g. Young 1978, Coles \& Lee Long 1985, Worthington et al. 1991). Jet nets and drop traps attempt to capture all the animals in an area, whether they are above or buried in the substrate. In contrast, beam trawls, which are towed over the surface of the substrate, catch animals that are on, or disturbed from, the substrate and that could not avoid the net. Beam trawl catch data have been used in studies of long-term changes in relative abundance of crustaceans and fish by standardising the time of sampling to that of known catchability or highest catch rates (e.g. Staples \& Vance 1979, Staples et al. 1985). This requires a detailed understanding of how catch rates change with a number of factors, particularly tidal and lunar cycles (see Vance \& Staples 1992, Vance et al. 1994).

The juveniles of commercially important penaeid prawns (shrimp) are usually found in nursery habitats in shallow, inshore and estuarine waters (Dall et al. 1990). For example, juvenile brown and grooved tiger prawns Penaeus esculentus and $P$. semisulcatus are 
found on beds of seagrass and algae (Coles \& Lee Long 1985, Staples et al. 1985, Vance \& Staples 1992), and juvenile brown shrimp $P$. aztecus live in salt marshes (Spartina alterniflora) (Zimmerman et al. 1984). As seagrasses in tropical Australia differ markedly in their morphology, some types may provide better habitat for juvenile tiger prawns than others (Poiner et al. 1987 , 1989, Loneragan et al. 1994). However, before one can evaluate this hypothesis, it is important to establish whether the sampling device is equally efficient in all seagrass communities.

Most species of prawns bury themselves during the day, and emerge from the substrate and become active at night (Dall et al. 1990, Wassenberg \& Hill 1994). Juvenile prawns are therefore usually sampled with small beam trawls at night (e.g. Young 1978, Turnbull \& Watson 1992, O'Brien 1994). The efficiencies of different beam trawl nets have been compared (McNeill \& Bell 1992, Turnbull \& Watson 1992) and the daytime efficiency of a beam trawl has been estimated for Penaeus aztecus in salt marshes (Zimmerman et al. 1984). However, we know of no estimates of the efficiency of beam trawls in different seagrass beds.

Both the efficiency of a net and the size of the population it is sampling can be estimated by 'removal experiments', whereby an area is repeatedly sampled over a relatively short time interval (e.g. Ricker 1975 Schnute 1983, Joll \& Penn 1990). Removal experiments, and the Leslie-DeLury techniques of data analysis, assume that the population is closed, and that the catchability of the target species is constant throughout the sampling period (Ricker 1975). Maximum-likelihood techniques have also been applied to the data from removal experiments to estimate net efficiency and population size (e.g. Seber \& Le Cren 1967. Schnute 1983, Riley \& Fausch 1992)

In this study we used removal methods to estimate the efficiency of a small beam trawl at night in different seagrass beds. The efficiency with which this net captured newly settled Penaeus esculentus and $P$. semisulcatus postlarvae (i.e. the first benthic stages) was compared with that for capturing juveniles. Its efficiency at capturing juvenile $P$. semisulcatus in deeper water (i.e. at high tide) was compared with its efficiency in shallower water (i.e. at low tide). The efficiency of the net was calculated by different methods (Leslie, DeLury, Maximum-likelihood) and the biases in these methods are discussed.

\section{MATERIALS AND METHODS}

Removal experiments. Removal experiments were used to estimate the efficiency of a small beam trawl at 2 intertidal seagrass beds (North West Reef and Black
Stump Bay) in northwestern Groote Eylandt (13 to $14^{\circ} \mathrm{S}, 135$ to $137^{\circ} \mathrm{E}$ ), and 1 intertidal seagrass bed in the Embley River $\left(12^{\circ} 40^{\prime} \mathrm{S}, 141^{\circ} 50^{\prime} \mathrm{E}\right)$ in the northeastern Gulf of Carpentaria, Australia. Only 1 seagrass community type was found at each site and thus the effects of site and seagrass type cannot be separated. The main species of seagrass at North West Reef was Thalassia hemprichii. The dominant seagrasses at Black Stump Bay were Syringodium isoetifolium and Cymodocea serrulata and in the Embley River, the main seagrass was Enhalus acoroides (see Table 1). At least 2 areas of seagrass were sampled at each site to provide an estimate of withinseagrass-bed variation.

Prawns were sampled at night at all sites because this is the time when juvenile tiger prawns are most active and beam trawl catches are highest (Vance 1992, Vance \& Staples 1992, Vance et al. 1994) Sampling was carried out between the spring and neap stage of the tidal cycle. The experiments at North West Reef were completed in January 1984 and those at Black Stump Bay in February 1984, both during the first quarter of the moon. The Embley River studies were completed in January 1991 during the last quarter of the moon.

The dimensions of the beam trawl used in the removal experiments were: mouth $1 \mathrm{~m}$ wide and $0.5 \mathrm{~m}$ high; body of the net, $2.5 \mathrm{~m}$ long with $2 \mathrm{~mm}$ mesh; codend, $1 \mathrm{~m}$ long with $1 \mathrm{~mm}$ mesh.

This net was repeatedly hand-hauled over a $40 \mathrm{~m}$ long $\times 3 \mathrm{~m}$ wide area of seagrass, marked out by posts and enclosed by a $2 \mathrm{~m}$ deep net, made of $6 \mathrm{~mm}$ mesh. The enclosure net was set around the posts while rowing a small dingy to create as little disturbance as possible. A dingy was moored at each end of the rectangle. The beam trawl was hand-hauled along the length of the rectangle, with 3 hauls required to completely sweep the enclosed area (up one side, down the middle, up the other side of the rectangle). Any catch was removed from the cod-end before the start of the next haul. Each $40 \mathrm{~m}$ haul took about $75 \mathrm{~s}$ to complete, which is about the same towing speed as that used when this net is towed by a small boat (ca 0.5 to $\left.0.6 \mathrm{~m} \mathrm{~s}^{-1}\right)$. The sequence of trawls was repeated until the rectangle had been swept 5 times (i.e. 15 trawls) within 75 to $90 \mathrm{~min}$ in all experiments, except one (North West Reef, Expt 2), when only 3 sweeps (i.e. 9 trawls) could be made before dawn.

Each removal experiment was completed on a previously untrawled area of seagrass. Two experiments were carried out at both Black Stump Bay and North West Reef. A total of 6 experiments ( 3 at high and 3 at low tide) were completed in the Embley Estuary on 3 consecutive nights, to investigate the influence of water depth on the efficiency of the net. 
Míéasuiements. The prowns from each trawl were placed on ice and taken to the laboratory where they were identified, counted and measured (carapace length, CL) to the nearest $1 \mathrm{~mm}$ under a dissecting microscope. Although the postlarvae of the tiger prawn group ( $<3 \mathrm{~mm} \mathrm{CL}$ ) could be distinguished from other penaeid postlarvae groups (e.g. banana prawns Penaeus merguinensis and $P$. indicus, king prawns $P$. latisulcatus and $P$. longistylis, and greasy prawns Metapenaeus spp.), they could not be identified to species. Juvenile tiger prawns $\geq 3 \mathrm{~mm}$ CL were identified from the characteristics outlined by Grey et al. (1983). Mean carapace lengths were calculated for juvenile tiger prawns ( $\geq 3 \mathrm{~mm} \mathrm{CL}$ ) for each removal experiment where more than 25 prawns were caught.

Seagrass. Samples of seagrass were collected from North West Reef in December 1983, from Black Stump Bay in February 1984 and from the Embley River in November 1990. The sampling methods are described in Poiner et al. (1987). The total surface area of each species of seagrass was calculated from the sum of the surface areas of the leaves, stems and shoots. The mean total surface area, shoot density and aboveground biomass of seagrass per $\mathrm{m}^{2}$ were calculated for each site. The above-ground biomass for each species or taxon of algae was also calculated at each site, and summed to determine the total above-ground biomass for algae.

Calculation of net efficiency. Postlarvae and small juvenile prawns may have been able to emigrate from, or immigrate into, the enclosed seagrass area. However, because the experiments were completed within $90 \mathrm{~min}$, we have assumed that emigration and immigration from the enclosure were negligible. In addition, laboratory studies of juvenile Penaeus esculentus behaviour show that small tiger prawns move only short distances when disturbed (Kenyon 1993) and thus there was probably relatively little movement through the enclosure net in response to the passage of the beam trawl.

The data from the removal experiments were analysed as a special case of the Leslie-DeLury methods because equal units of effort were used to make the successive catches (Ricker 1975, Joll \& Penn 1990). Each group of 3 trawls that completely swept the rectangle (1 sweep) was used as the standard unit of effort, and the catch was the total catch from these 3 trawls. Only those experiments in which at least 25 individuals were caught were analysed to estimate net efficiency; this limited the data for postlarvae and juvenile Pendeus esculentus to Groote Eylandt experiments, and the data for juvenile $P$. semisulcatus to Embley River experiments. Full details of the notation and equations used to calculate net efficiency are given in the Anpendix. A brief description of each method is given below.

Leslie's method: This method is based on a linear regression of catch per unit effort (CPUE) on the cumulative catch to the start of the ith sweep (see Ricker 1975 , p. 151). A weighted Leslie regression was also calculated using the inverse of the catches as the weight for each point (see also Crittenden 1983).

DeLury's method: This method is based on the regression of $\ln (\mathrm{CPUE})$ in each sweep on the cumulative effort (E). Zero sweeps, which were only recorded on the last sweep of an experiment, were not included in these analyses.

Maximum-likelihood method: Schnute (1983) assumes that on the $i$ th sweep of the enclosure, each remaining prawn is exposed to capture with the same probability $q$ independently, i.e. the ith catch has a binomial distribution. The catchability $q$ is usually unknown and we assume that it is constant over the fishing interval $i$, which leads to Model 1 of Schnute (1983).

Comparisons of net efficiencies. Only pairwise comparisons were possible between size groups (i.e. postlarvae and juveniles), species of juvenile prawn, and seagrass types because catch rates of one or more groups were too low to allow broader comparisons to be made using analysis of covariance. The means and standard errors of $\hat{q}$ and $\hat{N}_{0}$ from each method of calculation (i.e. Leslie, weighted Leslie, DeLury and Maximum-likelihood) were calculated for postlarvae (both species combined), juvenile Penaeus esculentus, and juvenile $P$. semisulcatus at low and high tide. Differences in the Maximum-likelihood estimates of $q$ were calculated and $Z$-statistics (using the pooled variance) were used to test for differences in net efficiency and for constructing the $95 \%$ confidence intervals. The following comparisons in Maximum-likelihood net efficiency were made: (1) between seagrass types for postlarvae and juvenile $P$. esculentus; (2) between postlarvae and juvenile $P$. esculentus; (3) between high and low tide (i,e deep and shallow water) for juvenile $P$. semisulcatus; and (4) between juveniles of $P$. esculentus and $P$. semisulcatus in different seagrass types.

\section{RESULTS}

\section{Salinity, temperature and seagrass}

During the removal experiments mean temperature of the bottom waters ranged from 28.9 (Embley Estuary, low tide) to $30.6^{\circ} \mathrm{C}$ (North West Reef) and mean salinity from 33.2 (Black Stump Bay) to 36.5\% (North West Reef) (Table 1). Water depth was less than $1.2 \mathrm{~m}$ 
Table 1. Summary of environmental and macrophyte data for removal experiments. Values represent means, or means \pm 1 SE Seagrass data for January 1991 in the Embley River were collected in November 1990. Surface area of seagrass is per $m^{2}$ of substrate. AGB: above-ground biomass: Thalassia: T. hemprichii; Syringodium S. isoetifolium

\begin{tabular}{|c|c|c|c|c|}
\hline \multirow[t]{2}{*}{ Variable } & \multicolumn{2}{|c|}{ Groote Eylandt } & \multicolumn{2}{|c|}{ Embley River } \\
\hline & $\begin{array}{l}\text { North West Reef } \\
\operatorname{Jan} 1984\end{array}$ & $\begin{array}{c}\text { Black Stump Bay } \\
\text { Feb } 1984\end{array}$ & $\begin{array}{l}\text { Low tide } \\
\text { Jan } 1991\end{array}$ & $\begin{array}{l}\text { High tide } \\
\text { Jan } 1991\end{array}$ \\
\hline \multicolumn{5}{|l|}{ Environment } \\
\hline Temperature $\left({ }^{\circ} \mathrm{C}\right)$ & 30.6 & 29.4 & $28.9 \pm 0.5$ & $29.3 \pm 0.4$ \\
\hline Salinity $(\%)$ & $36.5 \pm 0.04$ & $33.2 \pm 0.39$ & $35.3 \pm 0.4$ & $35.1 \pm 0.5$ \\
\hline Mean depth (m) & $0.85 \pm 0.25$ & $0.95 \pm 0.04$ & $0.40 \pm 0.08$ & $1.75 \pm 0.11$ \\
\hline \multicolumn{5}{|l|}{ Macrophytes } \\
\hline Seagrass AGB $\left(\mathrm{g} \mathrm{m}^{-2}\right)$ & 54.0 & 204.1 & \multicolumn{2}{|c|}{75.5} \\
\hline Surface area $\left(\mathrm{m}^{2}\right)$ & 1.63 & 7.52 & \multicolumn{2}{|c|}{2.28} \\
\hline Shoot density $\left(\mathrm{n} \mathrm{m}^{-21}\right)$ & 816.6 & 6357.8 & \multicolumn{2}{|c|}{2493.0} \\
\hline $\begin{array}{l}\text { Main species by } A G B \\
(\%)\end{array}$ & $\begin{array}{c}\text { Thalassia } \\
(67.8)\end{array}$ & $\begin{array}{l}\text { Syringodium } \\
(73.9)\end{array}$ & \multirow{2}{*}{\multicolumn{2}{|c|}{$\begin{array}{c}\text { Enhalus acoroides } \\
(98.0) \\
0\end{array}$}} \\
\hline Algae AGB $\left(\mathrm{g} \mathrm{m}^{-2}\right)$ & 99.1 & 37.3 & & \\
\hline
\end{tabular}

during the studies on postlarvae and $1.0 \mathrm{~m}$ for juvenile Penaeus esculentus at the Groote Eylandt sites. The mean water depths on the Embley River seagrass bed were about 0.4 at low tide (range $=0.2$ to $0.5 \mathrm{~m}$ ) and $1.8 \mathrm{~m}$ at high tide (range $=1.6$ to $1.9 \mathrm{~m}$ ).

The mean above-ground biomass of seagrass ranged from $54 \mathrm{~g} \mathrm{~m}^{-2}$ (Thalassia hemprichii) at North West Reef to $204 \mathrm{~g} \mathrm{~m}^{-2}$ (mainly Syringodium isoetifolium with some Cymodocea serrulata) at Black Stump Bay (Table 1). The density of seagrass shoots at North West Reef was about a third of that at Black Stump Bay and one-eighth of that at the Embley River. At this latter site, Halodule uninervis, a small thin seagrass with many shoots, comprised $2 \%$ of the above-ground biomass but was found at very high shoot densities. Algae, mainly Caulerpa microphylla, were a significant component of the total above-ground biomass of all macrophytes at North West Reef (Table 1).

\section{Carapace lengths and catches from removal experiments}

The mean CL for juvenile Penaeus esculentus (range of means $=6.7$ to $7.5 \mathrm{~mm}$ ) and $P$. semisulcatus (range $=$ 6.4 to $7.6 \mathrm{~mm}$ ) were very consistent at the 3 sites and in

Table 2. Penaeus esculentus and $P$. semisulcatus. Total numbers of postlarvae (both species combined) and juvenile prawns caught in each sweep of the enclosure by a small beam trawl and total catches for each experiment. NWR: North West Reef; BSB: Black Stump Bay; Embley: Embley River; Thalassia: T. hemprichii, Syringodium: S. isoetifolium; Enhalus: E. acoroides. - Only 3 sweeps conducted

\begin{tabular}{|c|c|c|c|c|c|c|c|c|}
\hline $\begin{array}{c}\text { Expt } \\
\text { no. }\end{array}$ & Site, seagrass, tidal state & Date & 1 & 2 & $\begin{array}{c}\text { Swee } \\
3\end{array}$ & 4 & 5 & $\begin{array}{l}\text { Total } \\
\text { catch }\end{array}$ \\
\hline \multicolumn{2}{|c|}{ Postlarvae } & 1984 & & & & & & \\
\hline 1 & NWR, Thalassia & $\operatorname{Jan}$ & 109 & 24 & 8 & 5 & 8 & 154 \\
\hline 2 & NWR, Thalassia & Jan & 45 & 15 & 7 & $\cdot$ & $\cdot$ & 67 \\
\hline 3 & BSB, Syringodium & Feb & 21 & 5 & 2 & 1 & 0 & 29 \\
\hline 4 & BSB, Syringodium & Feb & 43 & 5 & 3 & 2 & 0 & 53 \\
\hline \multicolumn{2}{|c|}{ Juvenile $P$. esculentus } & 1984 & & & & & & \\
\hline 1 & NWR, Thalassia & $\operatorname{Jan}$ & 19 & 9 & 5 & 3 & 0 & 36 \\
\hline 3 & BSB, Syringodium & Feb & 72 & 16 & 6 & 15 & 6 & 115 \\
\hline 4 & BSB, Syringodium & Feb & 16 & 11 & 9 & 4 & 1 & 41 \\
\hline \multicolumn{2}{|c|}{ Juvenile $P$. semisulcatus } & 1991 & & & & & & \\
\hline 5 & Embley, Enhalus, low tide & Jan & 50 & 28 & 26 & 1 & 12 & 117 \\
\hline 6 & Embley, Enhalus, low tide & Jan & 81 & 59 & 7 & 6 & 3 & 156 \\
\hline 7 & Embley, Enhalus, low tide & Jan & 24 & 18 & 3 & 9 & 5 & 59 \\
\hline 8 & Embley, Enhalus, high tide & $\operatorname{Jan}$ & 16 & 19 & 10 & 7 & 2 & 54 \\
\hline 9 & Embley, Enhalus, high tide & $\operatorname{Jan}$ & 39 & 15 & 21 & 10 & 8 & 93 \\
\hline
\end{tabular}


(a) Leshe

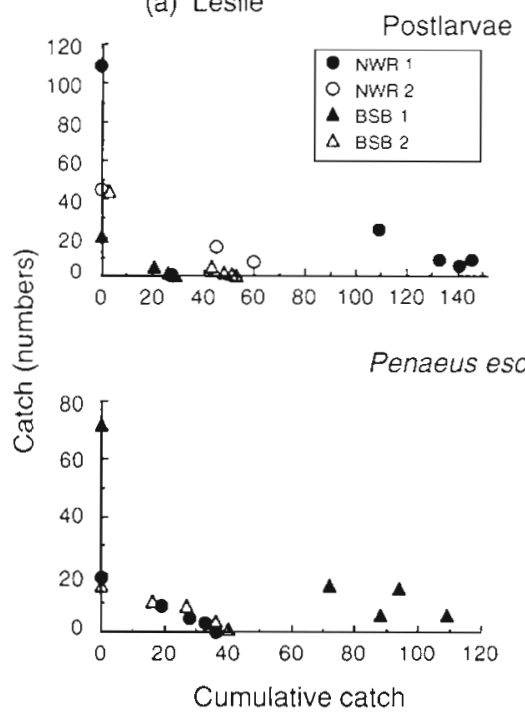

(iv) DéLiury

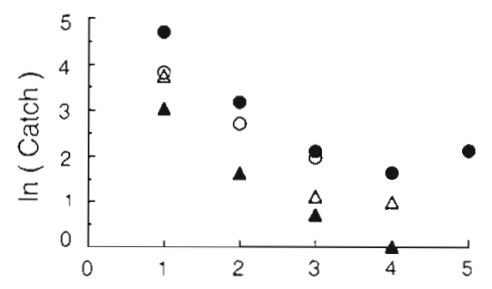

Fig. 1. Penaeus esculentus and P. semisulcatus. (a) Leslie and (b) DeLury relationships for postlarvae (both species combined), and juvenile $P$. esculentus from removal experiments with a small beam trawl

sions $\left(0, C_{-}\right)$was well separated from subsequent points, which grouped closely together (Expts 1 and 3; Fig. 1, Table 2). The unweighted Leslie estimates of $q$ differed most from the weighted estimates in these cases (Table 3).

In general, the DeLury equation did not fit the data as well as the Leslie equation (Figs. 1 \& 2). Thus, not all 12 DeLury regression equations were significant: 7 were significant at $\mathrm{p}=0.05 ; 2$ at $0.05<\mathrm{p} \leq 0.10$; and 3 were not significant at $p=0.10$. High standard errors were recorded for the DeLury estimates of $q$ for postlarvae in Expts 1 and 4, for Penaeus esculentus in Expt 3, and for $P$. semisulcatus in Expts 5 and 7 (Table 3). In these experiments, high proportions of prawns (>60\%) were caught in the first 1 or 2 sweeps of the enclosure (Table 2, Figs. $1 \& 2$ ).

The estimated efficiencies of the beam trawl calculated by each of the 4 meth- the different experiments. Most P. esculentus (92\%) and $P$. semisulcatus ( $82 \%$ ) were less than $10 \mathrm{~mm}$ in CL.

Only experiments where the total number of individuals exceeded 25 were used in the analysis of the removal experiments (Table 2): 4 experiments met this criterion for postlarvae (of both species combined), 3 for juvenile Penaeus esculentus and 5 for juvenile $P$. semisulcatus, all in the Embley River (Table 2). There were no experiments in which 25 juveniles of both tiger prawn species were caught.

Catches of postlarvae in the first sweep of the enclosure ranged from 67 to $81 \%$ of the total catch of postlarvae in each experiment, while those of juvenile Penaeus esculentus ranged from 39 to $63 \%$ of the total catch (Table 2). Catches of juvenile P. semisulcatus ranged from 30 to $52 \%$ of the total catch in each experiment (Table 2).

\section{Estimates of net efficiency}

The regressions used to obtain the parameters to estimate $q$ for the Leslie and weighted Leslie models were significant, or close to significant (i.e. 0.05 $<p \leq 0.10$ ) in all cases (Figs. $1 \& 2$ ). The first point in some of the Leslie regresods (Leslie, weighted Leslie, DeLury and Maximumlikelihood) were always higher for postlarvae than for juvenile Penaeus esculentus or juvenile $P$. semisulcatus (Table 3). Estimates of net efficiency for juveniles of $P$. esculentus and those for $P$. semisulcatus at low tide were similar in magnitude and, in all cases except 1 (DeLury, Expt 7), were higher than the estimated efficiencies for $P$. semisulcatus at high tide (Table 3). (a) Leslie

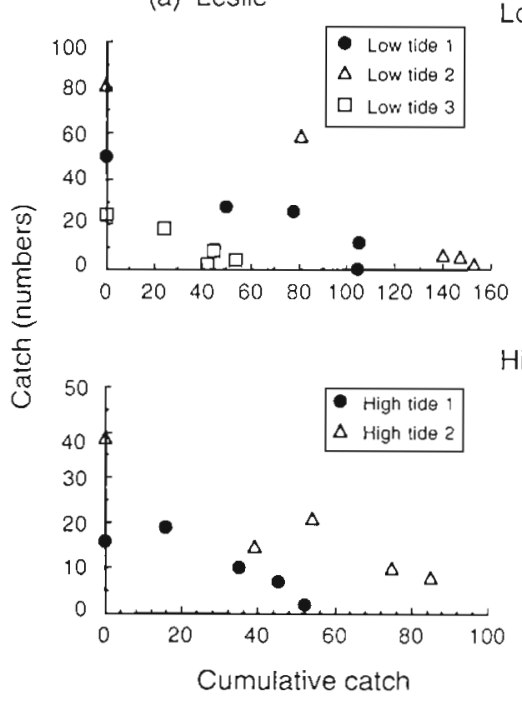

(b) DeLury

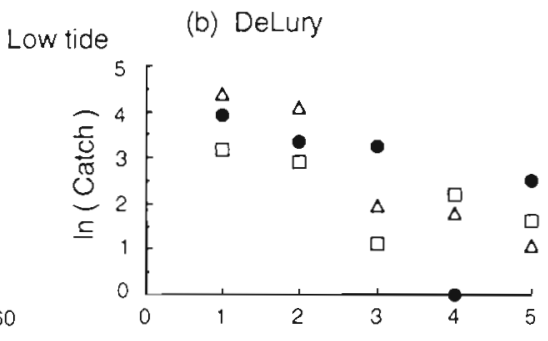

High tide

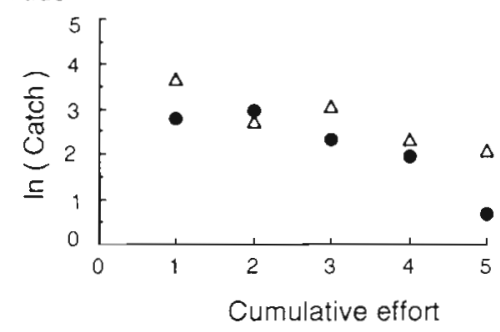

Fig. 2. Penaeus semisulcatus. (a) Leslie and (b) DeLury relationships for juvenile prawns from removal experiments with a small beam trawl 
Table 3. Penaeus esculentus and $P$. semisulcatus. Estimates of the absolute value of the efficiency $q$ ( \pm 1 SE) with which a small beam trawl captured tiger prawns in different seagrass beds during removal experiments. NWR: North West Reef; BSB: Black Stump Bay; Embley: Embley River; Thalassia: I hemprichii; Syringodium: S. isoetifolium; Enhalus: E. acoroides

\begin{tabular}{|c|c|c|c|c|c|}
\hline $\begin{array}{l}\text { Expt. } \\
\text { no. }\end{array}$ & Site, seagrass, tidal state & Leslie & $\begin{array}{c}\text { Weighted } \\
\text { Leslie }\end{array}$ & DeLury & $\begin{array}{l}\text { Maximum- } \\
\text { lkelihood }\end{array}$ \\
\hline \multicolumn{6}{|c|}{ Postlarvae } \\
\hline 1 & NWR, Thalassia & $0.73 \pm 0.04$ & $0.67 \pm 0.10$ & $0.51 \pm 0.17$ & $0.63 \pm 0.04$ \\
\hline 2 & NWR, Thalassia & $0.64 \pm 0.03$ & $0.63 \pm 0.04$ & $0.61 \pm 0.06$ & $0.66 \pm 0.06$ \\
\hline 3 & BSB, Syringodium & $0.72 \pm 0.02$ & $0.70 \pm 0.04$ & $0.64 \pm 0.08$ & $0.63 \pm 0.15$ \\
\hline \multirow[t]{2}{*}{4} & BSB, Syringodium & $0.82 \pm 0.04$ & $0.74 \pm 0.09$ & $0.64 \pm 0.19$ & $0.71 \pm 0.29$ \\
\hline & Mean & 0.73 & 0.69 & 0.60 & 0.66 \\
\hline \multicolumn{6}{|c|}{ Juvenile $P$. esculentus } \\
\hline 1 & NWR, Thalassia & $0.51 \pm 0.02$ & $0.53 \pm 0.05$ & $0.46 \pm 0.03$ & $0.51 \pm 0.10$ \\
\hline 3 & BSB, Syringodium & $0.63 \pm 0.09$ & $0.49 \pm 0.16$ & $0.41 \pm 0.19$ & $0.51 \pm 0.04$ \\
\hline \multirow[t]{2}{*}{4} & BSB, Syringodium & $0.36 \pm 0.04$ & $0.41 \pm 0.04$ & $0.49 \pm 0.10$ & $0.43 \pm 0.07$ \\
\hline & Mean & 0.50 & 0.48 & 0.45 & 0.49 \\
\hline \multicolumn{6}{|c|}{ Juvenile $P$. semisulcatus } \\
\hline 5 & Embley, Enhalus, low tide & $0.40 \pm 0.07$ & $0.50 \pm 0.13$ & $0.51 \pm 0.36$ & $0.40 \pm 0.04$ \\
\hline 6 & Enbley, Enhalus, low tide & $0.54 \pm 0.08$ & $0.56 \pm 0.08$ & $0.59 \pm 0.11$ & $0.59 \pm 0.03$ \\
\hline \multirow[t]{2}{*}{7} & Embley, Enhalus, low tide & $0.39 \pm 0.09$ & $0.37 \pm 0.15$ & $0.34 \pm 0.20$ & $0.38 \pm 0.06$ \\
\hline & Mean low tide & 0.44 & 0.48 & 0.48 & 0.46 \\
\hline 8 & Embley, Enhalus, high tide & $0.29 \pm 0.08$ & $0.33 \pm 0.07$ & $0.41 \pm 0.11$ & $0.36 \pm 0.07$ \\
\hline \multirow[t]{2}{*}{9} & Embley, Enhalus, high tide & $0.35 \pm 0.08$ & $0.30 \pm 0.08$ & $0.30 \pm 0.08$ & $0.34 \pm 0.05$ \\
\hline & Mean high tide & 0.32 & 0.32 & 0.36 & 0.35 \\
\hline
\end{tabular}

The Maximum-likelihood net efficiencies $(q)$ for postlarvae and juvenile Penaeus esculentus did not differ between the seagrasses at North West Reef and

Table 4. Penaeus esculentus and $P$. semisulcatus. Mean $( \pm 95 \%$ confidence limits, C.L.) Maximum-likelihood estimates of net efficiency $q$, and the results of comparisons between means. NWR: North West Reef; BSB: Black Stump Bay; Embley: Embley River; Thalassia: T hemprichii; Syringodium: S. isoetifolium; Enhalus: E. acoroides; ns: not significant

\begin{tabular}{|c|c|c|c|}
\hline Comparison & $\begin{array}{c}\text { Mean } \\
q \pm 95 \% \text { C.L. }\end{array}$ & $Z$-value & $\mathrm{p}$ \\
\hline \multicolumn{4}{|l|}{ Postlarvae } \\
\hline NWR, Thalassia & $0.64 \pm 0.07$ & 0.16 & ns \\
\hline BSB, Syringodium & $0.67 \pm 0.32$ & & \\
\hline Mean & $0.66 \pm 0.16$ & & \\
\hline \multicolumn{4}{|l|}{ Juvenile $P$. esculentus } \\
\hline NWR, Thalassia & $0.52 \pm 0.20$ & 0.50 & ns \\
\hline BSB, Syringodium & $0.47 \pm 0.08$ & & \\
\hline Mean & $0.49 \pm 0.09$ & & \\
\hline \multicolumn{4}{|l|}{ Juvenile $P$. semisulcatus } \\
\hline Embley, Enhalus, low tide $(\leq 0.5 \mathrm{~m})$ & $0.46 \pm 0.05$ & 2.20 & $<0.05$ \\
\hline Embley, Enhalus, high tide ( $\geq 1.6 \mathrm{~m})$ & $0.35 \pm 0.08$ & & \\
\hline \multicolumn{4}{|c|}{ Juveniles } \\
\hline P. esculentus, Thalassia, and Syringodium & $0.49 \pm 0.09$ & 0.54 & ns \\
\hline P. semisulcatus, Enhalus, low tide & $0.46 \pm 0.05$ & & \\
\hline Mean $(\leq 1.0 \mathrm{~m})$ & $0.47 \pm 0.05$ & & \\
\hline \multicolumn{4}{|l|}{ Life stage } \\
\hline Postlarvae, Thalassia, and Syringodium & $0.66 \pm 0.16$ & 6.64 & $<0.001$ \\
\hline Juveniles (both species, $\leq 1.0 \mathrm{~m}$ ) & $0.47 \pm 0.05$ & & \\
\hline
\end{tabular}

Black Stump Bay (Table 4). The overall mean Maximum-likelihood net efficiency $( \pm 95 \%$ confidence limits, C.L.) for postlarvae was $0.66 \pm 0.16$, while that for juvenile $P$. esculentus was $0.49 \pm 0.09$ While the Maximum-likelihood net efficiency for juvenile $P$. semisulcatus at low tide $(0.46 \pm 0.05)$ was significantly higher than that at high tide $(0.35 \pm 0.08)$, it did not differ from that for juvenile $P$. esculentus (Table 4). The overall mean net efficiency for juvenile tiger prawns (i.e. both $P$. esculentus and $P$. semisulcatus) in water less than $1.0 \mathrm{~m}$ deep $(0.47 \pm 0.05)$ was significantly lower than the overall mean for postlarvae (Table 4).

\section{Estimates of initial population size}

The Leslie, weighted Leslie and Maximum-likelihood estimates of the initial population size were within 10 prawns of the total catch in all cases, except Expt 5 (Penaeus semisulcatus at low tide; Table 5). By contrast, the DeLury estimates were lower than the total catch by 10 or more prawns in 5 experiments (postlarvae, 1 and 4; $P$. esculentus, Expt $3_{i} P$. semisulcatus, 
Table 5. Penaeus esculentus and $P$. semisulcatus. Estimates of the initial population size of tiger prawns and the total catch from a small beam trawl during removal experiments. NWR: North West Reef; BSB: Black Stump Bay; Embley: Embley River; Thalassia: T. hemprichi; Syringodium: S. isoetifolium; Enhalus: E. acoroides

\begin{tabular}{|c|c|c|c|c|c|c|}
\hline $\begin{array}{l}\text { Expt } \\
\text { no. }\end{array}$ & Site, seagrass, tidal state & Leslie & $\begin{array}{l}\text { Weighted } \\
\text { Leslie }\end{array}$ & DeLury & $\begin{array}{l}\text { Maximum- } \\
\text { lıkelihood }\end{array}$ & Total catch \\
\hline \multicolumn{7}{|c|}{ Postlarvae } \\
\hline 1 & NWR, Thalassia & 148.2 & 149.9 & 120.7 & 155.0 & 154 \\
\hline 2 & NWR, Thalassia & 69.8 & 70.6 & 70.3 & 70.0 & 67 \\
\hline 3 & BSB, Syringodium & 28.8 & 29.1 & 27.1 & 30.0 & 29 \\
\hline 4 & BSB, Syringodium & 51.9 & 52.7 & 41.4 & 54.0 & 53 \\
\hline \multicolumn{7}{|c|}{ Juvenile $P$. esculentus } \\
\hline 1 & NWR, Thalassia & 37.4 & 36.7 & 38.9 & 37.0 & 36 \\
\hline 3 & BSB, Syringodium & 109.0 & 113.0 & 99.7 & 118.0 & 115 \\
\hline 4 & BSB, Syringodium & 46.9 & 43.4 & 43.4 & 43.0 & 41 \\
\hline \multicolumn{7}{|c|}{ Juvenile $P$. semisulcatus } \\
\hline 5 & Embley, Enhalus, low tide & 125.7 & 108.4 & 100.3 & 127.0 & 117 \\
\hline 6 & Embley, Enhalus, low tide & 161.8 & 157.3 & 143.7 & 157.0 & 156 \\
\hline 7 & Embley, Enhalus, low tide & 63.3 & 60.2 & 60.7 & 65.0 & 41 \\
\hline 8 & Embley, Enhalus, high tide & 67.2 & 60.6 & 58.7 & 61.0 & 54 \\
\hline 9 & Embley, Enhalus, high tide & 104.2 & 109.1 & 107.4 & 107.0 & 93 \\
\hline
\end{tabular}

Expts 5 and 6), and exceeded the total catch by more than 10 prawns for $P$. semisulcatus in Expt 7 (Table 5).

\section{DISCUSSION}

\section{Calculating net efficiency}

Few estimates of absolute efficiency have been made for the nets that are used to catch fish and crustaceans in inshore marine and estuarine nursery habitats (Allen et al. 1992). In our study, we used removal experiments to estimate the efficiency of a beam trawl for capturing small tiger prawns in 3 of the tropical seagrass communities in the Gulf of Carpentaria, northern Australia. The Maximum-likelihood method of estimating efficiency or catchability $(q)$ from removal experiments is the preferred one because it makes the fewest assumptions, and poses no computational problems when no individuals are caught (Schnute 1983). Although the computation for the Maximum-likelihood method appears to be more complicated than those for the Leslie and DeLury methods, the calculations are readily completed when the maximisation is for only 1 parameter. Our results show that the DeLury estimates of both $q$ and $N_{0}$ become unreliable when $q$ is high and the catches decline to low values during an experiment (see also Seber \& Le Cren 1967, Ricker 1975). When catches are very high in the first sweep of the net, the unweighted Leslie gives higher estimates of $q$ than the Maximumlikelihood.

\section{Differences in net efficiency between sizes of prawns and types of seagrass}

The results from our study provide initial estimates of net efficiency for a beam trawl net in capturing small tiger prawns. The catches of postlarve and juveniles were not sufficient in each experiment to permit direct comparisons between the different size classes or between species. In addition, we were not able to sample the full range of seagrass types in the Gulf of Carpentaria. However, the estimates of efficiency and comparisons of net efficiency show some important trends. The efficiency of the small beam trawl at night differed more between postlarvae $(<3 \mathrm{~mm}$ CL) and juvenile ( $\geq 3 \mathrm{~mm} C L$ ) tiger prawns than between different types of seagrass, which differed greatly in their structure and biomass. Efficiency was higher for the postlarvae of tiger prawns (mean $\mathrm{ML}=0.66$ ) than for juvenile Penaeus esculentus (0.49) or juvenile $P$. semisulcatus $(0.47)$ in shallow water $(\leq 1.0 \mathrm{~m}$ deep). The higher net efficiency for postlarvae may be because postlarvae rarely bury in the substrate, even on unvegetated habitats (Kenyon 1993), and they may not move as quickly as juveniles to avoid the net.

In shallow water ( $\leq 1.0 \mathrm{~m}$ deep), net efficiency did not differ significantly between the juveniles (mainly 3 to $10 \mathrm{~mm}$ CL individuals) of the 2 species of tiger prawns. The Maximum-likelihood estimates of net efficiency for juvenile Penaeus esculentus and juvenile $P$. semisulcatus were higher in shallow (mean $q=0.47$ ) than deeper water ( 1.6 to $1.9 \mathrm{~m}$ deep, mean $q=0.35$ ). Moreover, the highest Maximum-likelihood estimate of $q$ for juvenile tiger prawns was obtained when the water 
was only $0.2 \mathrm{~m}$ deep. In the field, catches of juvenile tiger prawns are greater at low than at high tide (Vance \& Staples 1992, Vance et al. 1994). As juvenile tiger prawns in the laboratory are more active at high than at low tide (Vance 1992), the lower catches and net efficiencies at high tide could result from the prawns being distributed throughout the water column when they are more active. The prawns can also avoid the net in water deeper than $0.5 \mathrm{~m}$ by moving above its path, as well as to the side and below it.

Although our estimates of net efficiency were made by repeatedly hand-hauling the beam trawl, estimates from towing the beam trawl from an outboardpowered dingy are likely to be similar, i.e. at low tide, efficiency for capturing postlarvae is likely to be higher than that for juveniles, which in turn would be greater than that for juveniles at high tide. Towing nets by outboard dingy creates more disturbance in the path of the net, particularly in shallow waters, than handhauling. However, small tiger prawns move only short distances when disturbed, often to the nearest vegetation (Kenyon 1993). Thus, the efficiency of outboardtowed beam trawls may be close to that of a handhauled net.

Different species of prawns respond to light in varying degrees and, as a consequence, the proportion of the population that is buried during the day and night varies between species (Penn 1984, Wassenberg \& Hill 1994). The response of prawns to light and their degree of nocturnal activity has important implications for the proportion of prawns that will be caught by a net during the day. The daytime efficiency of a small beam trawl for capturing brown shrimp Penaeus aztecus was estimated at $23 \%$, based on comparisons of catches in a beam trawl and drop trap of known efficiency (Zimmerman et al. 1984). Since the catch rates of juvenile tiger prawns during the day, when the prawns are more often buried, are about half those at night (N. R. Loneragan, CSIRO Division of Fisheries, unpubl. data), the daytime efficiency of our net may also be about $25 \%$.

Our results for Penaeus semisulcatus show that the efficiency of the net can vary in adjacent areas of the same seagrass bed on consecutive nights (range for Maximum-likelihood $q$ at low tide $=0.38$ to 0.59 ). The net efficiency of a commercial otter trawl for large western king prawns $P$. latisulcatus ranged from 31 to $53 \%$ in 2 experiments on adjacent sandy areas (Joll \& Penn 1990). This variation in efficiency was thought to be due to variation in the amount of light reaching the substrate between the 2 experiments. Experimental studies have shown that large $P$. latisulcatus respond more strongly to light than large tiger prawns (Wassenberg \& Hill 1994). The net efficiency for juvenile tiger prawns is therefore likely to be less sensitive to changes in light than that for king prawns.

Because of the small range of water temperatures in our study, the changes in net efficiency are not likely to be due to differences in water temperature. However, in subtropical and temperate regions, net efficiency could vary greatly with temperature. Prawns spend more time buried and are less active at lower (particularly $<18^{\circ} \mathrm{C}$ ) than higher temperatures (Hill 1985). The efficiency of seine nets for capturing some species of fish also varies with temperature (Allen et al. 1992).

The relative net efficiency of both small and large beam trawls can vary markedly between different species of fish and crustaceans (Warburton 1989, McNeill $\&$ Bell 1992). A large beam trawl net ( $3 \mathrm{~m}$ in width) was more efficient at capturing juvenile Penaeus esculentus than several other species of crustaceans and fish (Warburton 1989), possibly because juvenile P. esculentus tend to stay in the seagrass, particularly when disturbed.

\section{Approaches to estimating net efficiency}

Our experiments suggest that if beam trawl catches of tiger prawns are standardised by the depth of sampling, comparisons can be made between catch rates in different types of seagrass. The strategy we used for estimating efficiency could not, however, be used to estimate net efficiency in deep water. Our estimates of net efficiency need to be confirmed by using different methods and net efficiency should also be estimated in different seagrass communities. In addition to the type of removal experiments we used, net efficiency has been estimated by: (1) comparing catch rates between 2 methods - one with known efficiency (Zimmerman et al. 1984); (2) removal experiments with marked individuals (Ricker 1975); and (3) removal experiments in which all remaining individuals are collected at the end of an experiment by using a toxicant, such as rotenone (Allen et al. 1992). Unfortunately, postlarvae and early juvenile stages of tiger prawns are too small to be tagged and apparently, they are not affected by rotenone. The suggestion that artificial seagrass beds could be seeded with individuals to provide alternative estimates of the efficiency of beam trawls warrants investigation (McNeill \& Bell 1992).

Acknowledgements. We thank N. Vance for assistance in the field and in sorting samples. J. Kerr advised us on some of the analyses of our data. N. Caputi, M. Thomas, I. Poiner, $\checkmark$. Mawson and an anonymous reviewer provided helpful comments on the manuscript. This study was partly funded by grants from the Fishing Industry Research Trust Account (82/13 and 89/13). 
Appendix. The notations and equations used to calculate net efficiency

\begin{tabular}{|c|c|}
\hline$N_{0}$ & Initial population size before trawling \\
\hline$N_{1}$ & $\begin{array}{l}\text { Expected number in the population remaining after } \\
\text { the ith sweep of the enclosure }\end{array}$ \\
\hline q & $\begin{array}{l}\text { Proportion of the population caught during each } \\
\text { sweep }\end{array}$ \\
\hline$C_{1}$ & Expected catch during the ith sweep \\
\hline$T_{1}$ & $\begin{array}{l}\sum_{j=1}^{i} C_{j} \text {, the sum of the expected catches including the } \\
i \text { th sweep }\end{array}$ \\
\hline$k$ & Total number of sweeps of the enclosure \\
\hline
\end{tabular}

In this study we are mainly interested in estimating the catch efficiency $(q)$, and secondarily in estimating the initial population size $\left(N_{0}\right)$, where:

$$
N_{1}=N_{1-1}-C_{1} \text { and } C_{i}=q N_{1-1} i i=1,2, \ldots, 5
$$

In the equations below, a variable with a "indicates that it is an observed variable, or that it has been estimated from the observed data.

\section{Leslie's method}

Clearly:

$$
C_{1}=q\left(N_{0}-T_{1-1}\right),
$$

where $T_{0}$ is defined to be 0 and the first regression point is therefore $\left(0, C_{1}\right)$. The regression equation can now be written in the form of $y=a+b x$, with $a=q N_{0}$ and $b=-q$. The estimates of $q$ and $N_{0}$ are therefore: $(\hat{q})=-\hat{b}$ and $\hat{N}_{0}=-\hat{a} / \hat{b}$.

The estimate of $q$ is unbiased as the expectation of $\hat{q}=q$.

\section{DeLury's method}

Simple algebra leads to:

$$
C_{1}=q(1-q)^{1-1} N_{0}
$$

Using natural logarithms, we derive:

$$
\ln C_{i}=1 \ln (1-q)+\ln \left[q N_{0} /(1-q)\right] \text {. }
$$

This regression function can then be written in the form of $y=a+b x$, with

$$
a=\ln \left[q N_{0} /(1-q)\right] \text { and } b=\ln (1-q) \text {. }
$$

The estimates of $\left(q, N_{0}\right)$ are therefore

$$
\hat{q}=1-\mathrm{e}^{\dot{b}}, \hat{N}_{0}=\mathrm{e}^{\hat{a}+\hat{b}} /\left(1-\mathrm{e}^{\hat{b}}\right)
$$

The underlying model is that $\ln C_{j}$ has an error term with a normal distribution $N\left(0, \sigma^{2}\right)$. However, $1-\mathrm{e}^{\hat{b}}$ is not an unbiased estimate of $q=1-\mathrm{e}^{b}$ and the corrected estimate of $q$ to the first order is given by:

$$
\hat{q}_{c}=1-e^{\hat{b}}\left(1-r_{o}^{2} / 2\right),
$$

where $r_{\alpha}$ is the standard error of $\hat{b}$ (see Lindley 1965, $p$. $134-136$ ).

\section{Maximum-likelihood method}

If $k$ sweeps of the enclosure are made, the maximum-likelihood estimate of $q$ is given by:

$$
\hat{q}_{c}=\hat{T}_{k} /\left(k \hat{N}_{0}-\sum_{i=1}^{k-1} T_{1}\right)
$$

Therefore, maximising the likelihood can be made with respect to 1 parameter $\left(N_{0}\right)$. The estimate of $q$ can be obtained after $\hat{N}_{0}$ is found.

\section{LITERATURE CITED}

Allen, D. M., Service, S. K., Ogburn-Matthews, M. V. (1992). Factors influencing the collection efficiency of estuarine fishes. Trans. Am. Fish. Soc, 121: 234-244

Coles, R. G., Lee Long, W. J. (1985). Juvenile prawn biology and the distribution of seagrass prawn nursery grounds in the southeastern Gulf of Carpentaria. In: Rothlisberg, P. C., Hill, B. J., Staples, D. J. (eds.) Second Australian National Prawn Seminar. NPS2, Cleveland, Australia, p. $55-60$

Crittenden, R. N. (1983). An evaluation of the Leslie-DeLury method and of a weighted method for estimating the size of a closed population. Fish. Res. 2: 149-158

Dall, W., Hill, B. J., Rothlisberg, P. C., Staples, D. J. (1990). The biology of the Penaeidae. Adv. Mar. Biol. 27: 1-489

Grey, D. L., Dall, W., Baker, A. (1983). A guide to the Australian penaeid prawns. Department of Primary Production, Northern Territory, Darwin, Australia

Hill, B. J. (1985). Effect of temperature on duration of emergence, speed of movement, and catchability of the prawn penaeus esculentus. In: Rothlisberg, P. C., Hill, B. J., Staples, D. J. (eds.) Second Australian National Prawn Seminar. NPS2, Cleveland, Australia, p. 77-83

Joll, L. M., Penn, J. W. (1990). The application of high-resolution navigation systems to Leslie-DeLury depletion experiments for the measurement of trawl efficiency under open-sea conditions. Fish. Res. 9: 41-55
Kenyon, R. A. (1993). Factors affecting the distribution and abundance of juvenile tiger prawns, Penaeus esculentus and Penaeus semisulcatus, at Groote Eylandt, Northern Territory. M.Sc thesis, Griffith University, Brisbane

Lindley, D.V. (1965). Introduction to probability and statistics from a Bayesian viewpoint. Cambridge University Press, Cambridge

Loneragan, N. R., Kenyon, R. A., Haywood, M. D. E., Staples, D. J. (1994). Population dynamics of juvenile tiger prawns (Penaeus esculentus and Penaeus semisulcatus) in seagrass habitats of the western Gulf of Carpentaria, Australia. Mar. Biol. 119: 133-143

McNeill, S. E., Bell, J. D. (1992). Comparison of beam trawls for sampling macro-fauna of Posidonia seagrass. Estuaries 15: $360-367$

O'Brien, C. J. (1994). Population dynamics of juvenile tiger prawns Penaeus esculentus in south Queensland, Australia. Mar. Ecol. Prog. Ser. 104: 247-256

Penn, J. W. (1984). The behaviour and catchability of some commercially exploited penaeids and their relationship to stock and recruitment. In: Gulland, J. A., Rothschild, B. J. (eds.) Penaeid shrimps; their biology and management. Fishing News Books, Farnham, p. 173-186

Penn, J. W., Stalker, R. W. (1975). A daylight sampling net for juvenile penaeid prawns. Aust. J. mar. Freshwat. Res. 26: $287-291$

Poiner, I. R., Staples, D. J., Kenyon, R. (1987). Seagrass communities of the Gulf of Carpentaria, Australia. Aust. J. 
mar. Freshwat. Res. 38: 121-131

Poiner, I. R., Walker, D. I., Coles, R. G. (1989). Regional studies - seagrasses of tropical Australia. In: Larkum, A. D. W., McComb, A. J., Shepherd, S. (eds.) Biology of seagrasses: a treatise on the biology of seagrasses with special reference to the Australian region. Elsevier, Amsterdam, p. 279-303

Ricker, W. E. (1975). Computation and interpretation of the biological statistics of fish populations. Bull. Fish. Res. Bd Can. 191. 1-382

Riley, S. C., Fausch, K. D. (1992). Underestimation of trout population size by Maximum-likelihood removal estimates in small streams. N. Am. J. Fish. Manage. 12: $768-776$

Schnute, J. (1983). A new approach to estimating populations by the removal method. Can. J. Fish. Aquat. Sci. 40: $2153-2169$

Seber, G. A. F., Le Cren, E. D. (1967). Estimating population parameters from catches large relative to the population. J. Anim. Ecol. 36: 631-643

Staples, D. J., Vance, D. J. (1979). Effects of changes in catchability on sampling of juvenile and adolescent banana prawns, Penaeus merguiensis de Man. Aust. J. mar. Freshwat. Res. 30: 511-519

Staples, D. J., Vance, D. J., Heales, D. S. (1985). Habitat requirements of juvenile penaeid prawns and their offshore fisheries. In: Rothlisberg. P. C.. Hill, B. J.. Staples, D. J. (eds.) Second Australian National Prawn Seminar, NPS2. Cleveland, Australia, p. 47-54

Turnbull, C. T., Watson, R. A. (1992). Sledges for daytime

This article was presented by G. F. Humphrey (Senior

Editorial Advisor), Sydney, Australia sampling of juvenile penaeid shrimp. Fish. Res. 14: 31-40

Vance, D. J. (1992). Activity patterns of juvenile penaeid prawns in response to artificial tidal and day-night cycles: a comparison of three species. Mar. Ecol. Prog. Ser. 87: $215-226$

Vance, D. J., Heales, D. S., Loneragan, N. R. (1994). Seasonal, diel and tidal variation in beam trawl catches of juvenile grooved tiger prawns Penaeus semisulcatus (Decapoda: Penaeidae), in the Embley River, north-eastern Gulf of Carpentaria. Aust. J. mar. Freshwat. Res. 45: 35-42

Vance, D. J., Staples, D. J. (1992). Catchability and sampling of three species of juvenile penaeid prawns in the Embley River, Gulf of Carpentaria, Australia. Mar. Ecol. Prog. Ser. 87: $201-213$

Warburton, K. (1989). Catchability variation in short beam trawl hauls. Fish. Res. 7: 55-63

Wassenberg, T. J., Hill, B. J. (1994). Laboratory study of the effect of light on the emergence behaviour of eight species of commercially inportant adult penaeid prawns. Aust. J. mar. Freshwat. Res. 45: 43-50

Worthington, D. G., Ferrell, D. J., McNeill, S. E., Bell, J. D. (1991). Effects of shoot density of seagrass on fish and decapods: are correlations evident over large spatial scales? Mar. Biol. 112: 139-146

Young, P. C. (1978). Moreton Bay, Queensland: a nursery area for juvenile penaeid prawns. Aust. J. mar. Freshwat. Res. $2.9 \cdot 5.5-7.9$

Zimmerman, R. J., Minello, T. J., Zamora, G. (1984). Selection of vegetated habitat by brown shrimp, Penaeus aztecus, in a Galveston Bay salt marsh. Fish. Bull. U.S. 8: 325-336

Manuscript first received: June 21, 1994

Revised version accepted: September 14, 1994 